UDC 636.2.034

636.2.084.2:577.164.1

Original research paper

doi: 10.5937/AASer1846257H

Acta Agriculturae Serbica, Vol. XXIII, 46 (2018); 257-263

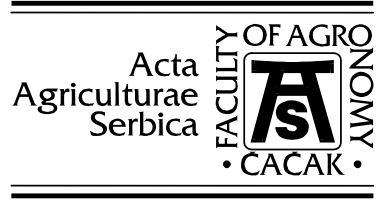

\title{
Influence of niacin administration on lipid peroxidation in cows in early lactation
}

\author{
Talija Hristovska ${ }^{1}$, Marko R. Cincovic ${ }^{2 *}$, Branislava Belić ${ }^{2}$, Dragica \\ Stojanović ${ }^{2}$, Radojica Đoković ${ }^{3}$, Zorana Kovačević ${ }^{2}$, Ivana Lakić ${ }^{2}$ \\ ${ }^{1}$ St. Clement of Ohrid University of Bitola, Faculty of Veterinary Medicine, \\ Macedonia; \\ ${ }^{2}$ University of Novi Sad, Faculty of Agriculture, Department of Veterinary \\ Medicine, Serbia; \\ ${ }^{3}$ University of Kragujevac, Faculty of Agronomy, Serbia \\ *Corresponding author: mcincovic@gmail.com
}

\begin{abstract}
Niacin is a reactive part of NAD and NADP, which are co-enzymes in numerous oxidative and reductive reactions. In early lactation, there is an increased lipid mobilization, accompanied by inflammatory response and oxidative stress. The aim of this study was to examine the effect of niacin administration in cows during early lactation in reducing lipid peroxidation i.e. MDA (malondialdehyde) concentration. Niacin was administered through feed two weeks before and two weeks after calving. Blood samples were taken in the week preceding calving and in the first and second week after calving. MDA concentration was significantly lower in cows receiving niacin compared to the control group during all three samplings: $1.89 \pm 0.33: 1.42 \pm 0.13$ (calving, week 0); 2.37 $\pm 0.41: 1.64 \pm 0.15$ (first week) and 2.6 $\pm 0.45: 1.8 \pm 0.17 \mu \mathrm{mol} / \mathrm{L}$ (second week). In control cows, no significant correlation between MDA and NEFA concentrations was found compared to cows fed niacin. In cows receiving niacin, the concentration of MDA linearly increased, as did the NEFA concentration. Niacin supplementation in early lactation can decreaselipid peroxidation in cows. Reduced lipid peroxidation in cows can be a consequence of the antilipolytic effect of niacin.
\end{abstract}

Keywords: cows, niacin, lipolysis, oxidative stress. 


\section{Introduction}

Niacin is reactive part of NAD and NADP, which are co-enzymes in numerous oxidative and reductive reactions. These enzymes are involved in the mechanism of hydrogen transfer in living cells, including more than 200 reactions of carbohydrates, lipid acids and amino acids. The most important metabolic reactions catalyzed by NAD and NADP are: carbohydrate metabolism (glycolysis - aerobic and anaerobic glucose oxidation, Krebs cycle), lipid metabolism (glycerol synthesis and glycerol degradation, oxidation of fatty acids and synthesis of fatty acids, steroid synthesis), protein metabolism (degradation and synthesis of amino acids, oxidation of carbon chains in the Krebs cycle (Cincović et al., 2018). Pires and Grummer (2007) used abomasal infusion with different concentrations of nicotinic acid (0.6, 30 and $60 \mathrm{mg} / \mathrm{kg}$ of body weight) in Holstein cows which received restricted diets. Abomasal infusion was administered as a single bolus dose 48 hours after feed restriction. One hour after the administration of $6 \mathrm{mg}$ nicotinic bolus, plasmatic NEFA concentration reduced from $546 \mu \mathrm{Eq} / \mathrm{l}$ to $208 \mu \mathrm{Eq} / \mathrm{l}$, and less than $100 \mu \mathrm{Eq} / \mathrm{l} 3$ hours after the infusion of the highest doses of nicotinic acid. The increase of nicotinic acid in the blood can reduce the phosphorylation of hormone-sensitive lipase and prevent increased lipolysis, which reduces plasma NEFA concentrations (Overton and Waldron, 2004; Morey et al., 2011; Kenéz, 2014).

In their review study, Ilkhani et al. (2016) showed that niacin administration can decrease lipid peroxidation and reduce MDA concentration in different experimental circumstances. During early lactation, greater lipomobilization occurs, accompanied by inflammatory response and oxidative stress (Cincović, 2016; Cincović and Starič, ed., 2017). The aim of this study was to determine the effect of niacin application in cows during early lactation in reducing lipid peroxidation i.e. the concentration of MDA as a by-product of lipid peroxidation.

\section{Materials and methods}

Cows and management - the experiment included 30 Holstein-Friesian cows in the second and third lactation with no signs of health disorders and with a milk yield of $7500 \pm 950$ liters. Cows were kept in a free stall system on deep litter. In the transitional period, they were kept in maternity stalls in a tie system. Feed was given in cycles but feeding in maternity stalls after calving was ad libitum. Cows were fed mixed feed that satisfied all their nutritional needs. Water was given ad libitum. Rations for cows in early lactation consisted of: proteins (17.519.5\% crude proteins, 30-33\% degradable proteins, 35-40\% non-degradable proteins), carbohydrates (ADF minimum 17-21\%, NDF minimum 28-31\%, NDF from voluminous feed minimum 18-23\%, non-structural carbohydrates 35-42\%, 
dry matter from voluminous feed minimum 40-45\%), energy (NEL 7-7.4 MJ/ kg of meal dry matter), fat per meal 5-7\%.

Niacin administration - niacin was administered through feed per os. Rovimix ${ }^{\circledR N i a c i n}$ was used in a dose that allowed availability in intestines at 6$12 \mathrm{~g}$ per day (60-120 g per cow per day). This concentration proved to be the best in previous experiments. Niacin was administered two weeks before and two weeks after calving.

Blood sampling and laboratory analysis - blood samples were taken from the coccygeal vein in cows before morning feeding to avoid the postprandial effect of the meal on metabolic parameters. Blood samples were taken at calving and in the first and second week after calving. Photometric reactions and Rayto (RT1904c) photometer were used. Measurements were conducted following the manufacturer's instructions. Standard kits of Randox (UK) and Pointe scientific (USA) were used.

Statistical analysis - differences in metabolite concentrations between the two groups of cows (cows receiving niacin and control cows ) were determined each week. The effect of week and group was determined by ANOVA and LSD test. The correlation between NEFA and MDA in experimental and control cows was determined. The Statgraphics Centurion statistical software package was used.

\section{Results and discussion}

MDA concentration was significantly reduced in cows receiving niacin compared to control cows in all three weeks of the experiment: $1.89 \pm 0.33: 1.42 \pm 0.13$ (calving, week 0); 2.37 $\pm 0.41: 1.64 \pm 0.15$ (first week) and 2.6 $\pm 0.45: 1.8 \pm 0.17 \mu \mathrm{mol} / \mathrm{L}$ (second week). ANOVA analysis showed that week of sampling and niacin administration had a very significant effect on MDA concentration in blood samples $(\mathrm{F}=32.46$; $\mathrm{p}<0.0001)$. LSD test showed that cows receiving niacin had lower levels of MDA in all weeks of the experiment. In both groups of cows, a significant increase in MDA was observed in the period from calving to the second week after calving. However, the blood of cows that received niacin showed no significant increase in MDA in the second week compared to the first one.

Experimental cows showed no statistical correlations between MDA and NEFA, unlike control cows, which exhibited a linear increase in NEFA and MDA.

Malondialdehyde (MDA) is a final product of half-saturated fatty acid peroxidation in the cells. The increase in free radicals can cause the hyperproduction of MDA, which is known as a marker of oxidative stress (Gawel et al., 2004). MDA concentration was higher after calving in dairy cows and showed a positive correlation with NEFA and BHB concentrations (Bernabucci 
et al., 2005). This experiment showed that week of sampling and niacin administration had a significant influence on MDA concentration in blood samples $(p<0.0001)$. MDA concentration was significantly lower in cows receiving niacin compared to control cows during all three weeks of the experiment. Lower NEFA concentrations in cows receiving niacin were related to lower MDA values during the experiment. Yuan et al. (2012) examined the antioxidant level and superoxide dismutase (SOD) in cows during the peripartal period after niacin administration and showed no significant effect of niacin administration. Our results are consistent with the results of scientists who examined the effect of niacin on lipid peroxidation in different animal models. Models that had niacin deficiency showed greater lipid peroxidation. Models that received niacin showed reduced lipid peroxidation (Ghazi-Khansari et al. 2005; Cho et al., 2009; Perumal et al., 2005; Atac et al., 2006; Tupe et al., 2011; Doger et al., 2011).

Graphic 1. MDA concentration in cows receiving niacin and control cows in the period of $0-2$ weeks after calving

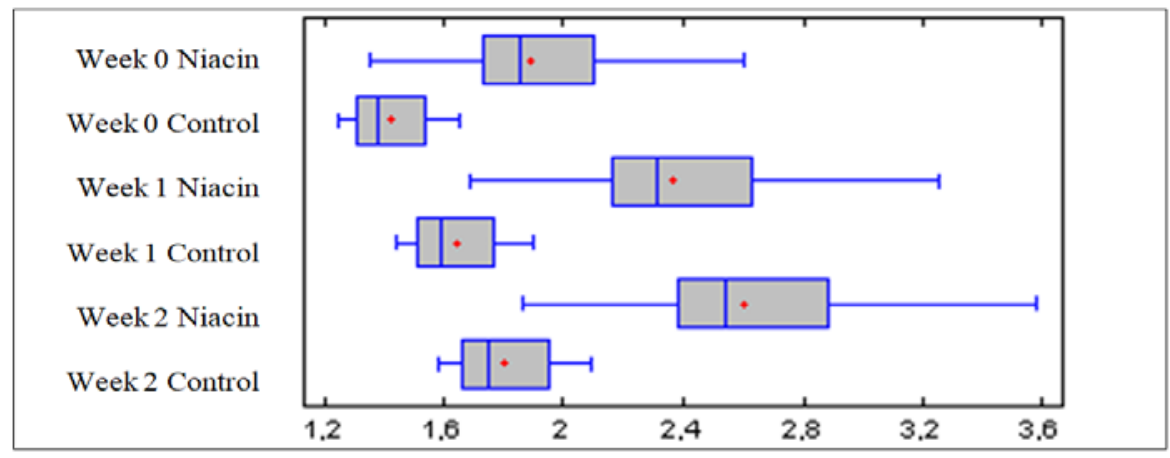

Graphic 2. Correlation between NEFA and MDA in niacin and control cows in all experimental weeks

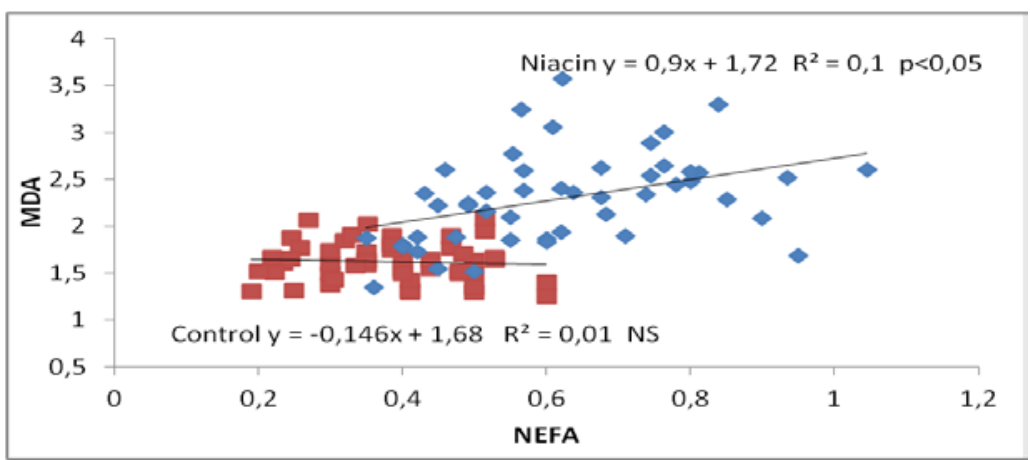


Table 1. LSD test of MDA value differences between different experimental groups for ANOVA analysis

\begin{tabular}{|l|l|l|}
\hline \multicolumn{1}{|c|}{ Contrast } & Sig. & Difference \\
\hline Week 0 Control - Week 0 Niacin & $\mathrm{p}<0.01$ & 0.467333 \\
\hline Week 0 Control - Week 1 Control & $\mathrm{p}<0.01$ & -0.474 \\
\hline Week 0 Control - Week 1 Niacin & $\mathrm{p}<0.01$ & 0.252 \\
\hline Week 0 Control - Week 2 Control & $\mathrm{p}<0.01$ & -0.710667 \\
\hline Week 0 Control - Week 2 Niacin & $\mathrm{NS}$ & 0.09 \\
\hline Week 0 Niacin - Week 1 Control & $\mathrm{p}<0.01$ & -0.941333 \\
\hline Week 0 Niacin - Week 1 Niacin & $\mathrm{NS}$ & -0.215333 \\
\hline Week 0 Niacin - Week 2 Control & $\mathrm{p}<0.01$ & -1.178 \\
\hline Week 0 Niacin - Week 2 Niacin & $\mathrm{p}<0.05$ & -0.377333 \\
\hline Week 1 Control - Week 1 Niacin & $\mathrm{p}<0.01$ & 0.726 \\
\hline Week 1 Control - Week 2 Control & $\mathrm{p}<0.05$ & -0.236667 \\
\hline Week 1 Control - Week 2 Niacin & $\mathrm{p}<0.01$ & 0.564 \\
\hline Week 1 Niacin - Week 2 Control & $\mathrm{p}<0.01$ & -0.962667 \\
\hline Week 1 Niacin - Week 2 Niacin & $\mathrm{NS}$ & -0.162 \\
\hline Week 2 Control - Week 2 Niacin & $\mathrm{p}<0.01$ & 0.800667 \\
\hline
\end{tabular}

\section{Conclusion}

Niacin administration during early lactation causes reduction in lipid peroxidation in cows. Reduced lipid peroxidation in cows could be a consequence of the antilipolytic effect of niacin.

\section{Acknowledgement}

This research is part of projects TR31062 and TR31095.

\section{References}

Atac I.A., Peksel A., Yanardag R., Sokmen B.B., Doger M.M., et al. (2006): The effect of combined treatment with niacin and chromium (iii) chloride on the different tissues of hyperlipemic rats. Drug and Chemical Toxicology, 29: 363-377.

Bernabucci U., Ronchi B., Lacetera N., Nardone A. (2005): Influence of body condition score on relationships between metabolic status and oxidative stress in periparturient dairy cows. Journal of Dairy Science, 88: 2017-2026.

Cho K.H., Kim H.J., Rodriguez-Iturbe B., Vaziri N.D. (2009): Niacin ameliorates oxidative stress, inflammation, proteinuria, and hypertension in rats with chronic renal failure. American Journal of Physiology-Renal Physiology, 297: F106-13.

Cincović M.R. (2016): Metabolički stres krava. Monografija. Poljoprivredni fakultet Novi Sad - Departman za veterinarsku medicinu. 
Cincović M.R., Starič J. (Ed.) (2017): Laboratorijska istraživanja metaboličkog statusa goveda. Monografija. Poljoprivredni fakultet Novi Sad - Departman za veterinarsku medicinu i Veterinarska fakulteta Ljubljana.

Cincović M., Hristovska T., Belić B. (2018): Niacin, Metabolic Stress and Insulin Resistance in Dairy Cows. In B Group Vitamins-Current Uses and Perspectives. IntechOpen.

Doger M.M., Sokmen B.B., Yanardag R. (2011): Combined effects of niacin and chromium treatment on heart of hyperlipidemic rats. Human \& Experimental Toxicology, 130: 1561-1566.

Gawel S., Wardas M., Niedworok E., Wardas P. (2004): Malondialdehyde (MDA) as a lipid peroxidation marker. Wiadomości Lekarskie, 57 (9-10): 453-455.

Ghazi-Khansari M., Nasiri G., Honarjoo M. (2005): Decreasing the oxidant stress from paraquat in isolated perfused rat lung using captopril and niacin. Archives of Toxicology, 79: 341-345.

Ilkhani F., Hosseini, B., Saedisomeolia A. (2016): Niacin and oxidative stress: a mini review. Journal of Nutritional Medicine and Diet Care, 2 (1): 2-014.

Kenéz A., Locher L. , Rehage J., Dänicke S., Huber K. (2014): Agonists of the G proteincoupled receptor 109A-mediated pathway promote antilipolysis by reducing serine residue 563 phosphorylation of hormone-sensitive lipase in bovine adipose tissue explants. Journal of Dairy Science, 97: 3626-3634.

Morey S.D., Mamedova L.K., Anderson D.E., Armendariz C.K., Titgemeyer E.C., Bradford B.J. (2011): Effects of encapsulated niacin on metabolism and production of periparturient dairy cows. Journal of Dairy Science, 94: 5090-5104.

Overton T.R., Waldron M.R. (2004): Nutritional management of transition dairy cows:strategies to optimize metabolic health. Journal of Dairy Science, 87: 105-119.

Perumal S.S., Shanthi P., Sachdanandam P. (2005): Augmented efficacy of tamoxifen in rat breast tumorigenesis when gavaged along with riboflavin, niacin, and coq10: Effects on lipid peroxidation and antioxidants in mitochondria. Chemico-Biological Interaction, 152: 49-58.

Pires J.A.A., Grummer R.R. (2007): The use of nicotinic acid to induce sustained low plasma nonesterified fatty acids in feed-restricted Holstein cows. Journal of Dairy Science, 90: 3725-3732.

Tupe R.S., Tupe S.G., Agte V.V. (2011): Dietary nicotinic acid supplementation improves hepatic zinc uptake and offers hepatoprotection against oxidative damage. British Journal of Nutrition, 105: 1741-1749.

Yuan K., Shaver R.D., Bertics S.J., Espineira M., Grummer R.R. (2012): Effect of rumen-protected niacin on lipid metabolism, oxidative stress, and performance of transition dairy cows. Journal of Dairy Science, 95: 2673-2679. 


\title{
UTICAJ APLIKACIJE NIACINA NA LIPIDNU PEROKSIDACIJU KOD KRAVA U RANOJ LAKTACIJI
}

\author{
Talija Hristovska ${ }^{1}$, Marko R. Cincovic ${ }^{2 *}$, Branislava Belić ${ }^{2}$, Dragica \\ Stojanović ${ }^{2}$, Radojica Đoković ${ }^{3}$, Zorana Kovačević ${ }^{2}$, Ivana Lakić ${ }^{2}$ \\ ${ }^{1}$ Univerzitet u Bitolju „Sv. Kliment Ohridski”, Veterinarski fakultet, \\ Makedonija; \\ ${ }^{2}$ Univerzitet u Novom Sadu, Poljoprivredni fakultet, Departman za veterinarsku \\ medicinu, Srbija; \\ ${ }^{3}$ Univerzitet u Kragujevcu, Agronomski fakultet Čačak, Srbija
}

\section{Rezime}

Niacin je reaktivna polovina NAD i NADP, koji su koenzimi u velikom broju oksidativnih i reduktivnih reakcija. U periodu rane laktacije postoji povećana lipidna mobilizacija, inflamatorni odgovor i oksidativni stres. Cilj ovog rada je da se ispita da li aplikacija niacina kod krava u ranoj laktaciji dovodi do smanjenja lipidne peroksidacije odnosno koncentracije MDA. Niacin je aplikovan putem hrane u periodu dve nedelje pre i dve nedelje posle teljenja. Krv je uzeta u nedelji teljenja a potom i u prvoj i drugoj nedelji posle teljenja. Koncentracija MDA je bila značajno niža kod krava koje su primale niacin u odnosu na kontrolnu grupu tokom sve tri nedelje ispitivanja: 1,89 $\pm 0,33: 1,42 \pm 0,13$ (teljenje, nulta nedelja); 2,37 $\pm 0,41: 1,64 \pm 0,15$ (prva nedelja) i 2,6 $\pm 0,45: 1,8 \pm 0,17 \mu \mathrm{mol} / \mathrm{L}$ (druga nedelja). Kod krava ogledne grupe nema statistički značajne korelacije između vrednosti MDA i NEFA, za razliku od kontrolne grupe koja nije primala niacin gde je koncentracija MDA linearno rasla sa porastom koncentracije NEFA. Upotreba niacina u ranoj laktaciji dovodi do smanjenja lipidne peroksidacije kod krava. Smanjena lipidna peroksidacija kod krava može biti posledica antilipolitičkog delovanja niacina.

Ključne reči: krave, niacin, lipoliza, oksidativni stres. 